\title{
Pengaruh Pelatihan dan Kompetensi Terhadap Kepuasan Kerja Melalui Motivasi Kerja
}

\author{
Anggi Meidita \\ Program Studi Magister Manajemen, Universitas Muhammadiyah Sumatera Utara Medan, Indonesia \\ Jl. Denai No. 217, Tegal Sari Mandala II, Medan Denai, Kota Medan, Sumatera Utara 20371 \\ Email: anggimeidiadita@gmail.com
}

\begin{abstract}
Abstrak. Berhasil tidaknya suatu perusahaan dalam mewujudkan tujuan yang diinginkan hal itu sangat bergantung kepada kualitas sumber daya manusia. Maka sudah semestinya PT. Perkebunan Nusantara IV (Persero) Medan memberikan rasa senang dalam diri setiap karyawan untuk menunjang pencapaian keinginan perusahaan. Penelitian ini bertujuan untuk mengetahui dan menganalisis Pengaruh pelatihan dan kompetensi terhadap kepuasan kerja melalui motivasi kerja pada karyawan.Penelitian ini menggunakan pendekatan asosiatif populasi 101 dan sampel yang digunakan sebanyak 101 karyawan yaitu menggunakan sampel jenuh. Serta penelitian ini menggunakan teknik analisis jalur (path analysis). Hasil penelitian ini terlihat bahwa pelatihan berpengaruh signifikan terhadap motivasi kerja, kompetensi berpengaruh signifikan terhadap motivasi kerja, pelatihan berpengaruh signifikan terhadap kepuasan kerja, kompetensi tidak berpengaruh terhadap Kepuasan kerja, motivasi kerja berpengaruh signifikan terhadap kepuasan kerja, pelatihan berpengaruh langsung terhadap kepuasan kerja tidak melalui motivasi kerja, kompetensi berpengaruh tidak langsung terhadap kepuasan kerja melalui Motivasi Kerja.
\end{abstract}

Kata kunci: Kepuasan Kerja, Motivasi Kerja, Pelatihan, Kompetensi

\begin{abstract}
The success or failure of a company in realizing its desired goals is very dependent on the quality of human resources. Then it should be PT. Perkebunan Nusantara IV (Persero) Medan provide a sense of pleasure in each employee to support the achievement of the company's desires. This study aims to determine and analyze the effect of training and competence on job satisfaction through work motivation on employees. This study uses a population 101 associative approach and the sample used by 101 employees is using saturated samples. And this study uses path analysis techniques (path analysis). The results of this study show that training has a significant effect on work motivation, competence has a significant effect on work motivation, training has a significant effect on job satisfaction, competence does not affect job satisfaction, work motivation has a significant effect on job satisfaction, training directly affects job satisfaction not through motivation work, competence has an indirect effect on job satisfaction through Work Motivation
\end{abstract}

Keywords : Job Satisfaction, Work Motivation, Training, Competence

\section{PENDAHULUAN}

Karyawan adalah asset utama perusahaan yang menjadi perencana dan pelaku aktif dari setiap aktivitas organisasi (Arianty, Bahagia, Lubis, \& Siswadi, 2016). Mereka mempunyai pikiran, perasaan, keinginan, status, dan latar belakang pendidikan, usia, dan jenis kelamin yang heterogen yang dibawa kedalam organisasi perusahaan. Semula sumber daya manusia merupakan terjemahan dari "human resources", namun ada pula ahli yang menyamakan sumber daya manusia dengan "manpower" (tenaga kerja). Bahkan sebagian orang menyetarakan pengertian sumber daya manusia dengan personal (personalia, kepegawaian, dan sebagainya). Menurut Kasmir Sumber daya manusia merupakan proses pengelolaan manusia, melalui perencanaan, rekrutmen, seleksi, pelatihan , pengembangan, pemberian kompensasi, karier, keselamatan, dan kesehatan serta menjaga hubungan industrial sampai pemurusan hubungan kerja dan peningkatan kesejahteraan stakeholder. Sutrisno (2016), oleh sebab itu 
perusahaan yang menyatakan karyawan adalah asset yang harus dipertahankan. Perusahaan harus memberikan rasa puas karyawan dalam bekerja. Kepuasan kerja pada dasarnya merupakan sesuatu yang bersifat individual, kerean setiap individu memiliki tingkat kepuasan yang berbeda-beda sesuai dengan sistem nilai yang berlaku pada dirinya. Kepuasan kerja merupakan evaluasi yang menggambarkan seseorang atas perasaan sikap senang atau tidak senang, puas atau tidak puas dalam bekerja. Kepuasaan kerja pegawai adalah suatu fenomena yang perlu dicermati oleh pimpinan organisasi (Jufrizen, 2016). Menurut Sutrisno, (2016), kepuasan kerja merupakan perasaan senang atau senang pekerja dalam memandang dan menjalankan pekerjaannya. Mangkunegara, (2017) mengemukakan faktor kepuasan kerja yaitu faktor yang ada pada diri karyawan, yaitu kecerdasan (IQ) kecakapan khusus umur, jenis kelamin, kondisi fisik, pendidikan, pengalaman kerja, kepribadian emosi cara berpikir, persepsi dan sikap kerja.Faktor pekerjaan, yaitu jenis pekerjaan, struktur organisasi, pangkat (golongan) kedudukan, mutu pengawasan, jaminan finansial dan kesempatan promosi. dan faktor - faktor lain yang dikemukakan oleh (Sutrisno, 2012) adalah sebagai berikut: Faktor psikologis, merupakan faktor yang berhubungan dengan kejiwaan karyawan, yang meliputi minat, ketentraman dalam kerja, sikap terhadap kerja, bakat, dan keterampilan. Faktor sosial, merupakan faktor yang berhubungan dengan internet aksi sosial antar karyawan maupun karyawan dengan atasan.Faktor fisik, merupakan faktor yang berhubungan dengan kondisi fisik karyawan, meliputi jenis pekerjaan, pengaturan waktu dan waktu istirahat, perlengkapan kerja, keadaan ruangan, suhu, penerangan, pertukaran udara, kondisi kesehatan karyawan, umur dan sebagainya. Faktor finansial, merupakan faktor yang berhubungan dengan jaminan serta kesejahteraan karyawan, yang meliputi sistem dan besarnya gaji, jaminan sosial, macam-macam tunjangan, fasilitas yang diberikan, promosi, dan sebagainya.

Dari faktor-faktor diatas maka tingkat kepuasan kerja yang harus ditingkatkan oleh perusahaan karena apabila seseorang senang dengan pekerjaannya, maka orang tersebut puas terhadap pekerjaannya, dengan terkait kepuasan kerja terlihat adanya beberapa karyawan yang masih memiliki keinginan yang belum dipenuhi perusahaan seperti kondisi dimana terkadang penerimaan gaji kurang tepat waktu dari janji awal saat melakukan perekrutan dan hasil kerja yang diberikan karyawan masih belum diakui pimpinan hal ini menyebabkan karyawan belum sepenuh hati dalam melakukan pekerjaan sehari- harinya.

Selain rasa senang yang harus dimiliki karyawan, perusahaan juga wajib memotivasi karyawan untuk lebih baik dalam pekerjaan. Motivasi merupakan salah satu hal yang mempengaruhi prilaku manusia. Motivasi disebut juga sebagai pendorong, keinginan, pendukung atau kebutuhankebutuhan yang dapat membuat seseorang bersemangat dan termotivasi untuk mengurangi serta memenuhi dorongan diri sendiri, sehingga dapat bertindak dan berbuat menurut cara-cara tertentu yang akan membawa ke arah yang optimal (Jufrizen, 2017). Sutrisno, (2016) menyatakan bahwa motivasi adalah suatu faktor yang mendorong seseorang untuk melakukan suatu aktivitas tertentu, oleh karena itu motivasi sering kali diartikan pula sebagai faktor pendorong perilaku seseorang. Setiap aktivitas yang dilakukan oleh seseorang pasti memiliki suatu faktor yang mendorong aktivitas tersebut.Faktor Internal yaitu keinginan untuk dapat hidup, keinginan untuk dapat memiliki, keinginan untuk dapat memperoleh penghargaan, keinginan untuk memperoleh pengakuan, keinginan untuk brkuasa sedangkan Faktor Eksternal yaitu kondisi lingkungan kerja, kompensasi yang memadai, supervisi yang baik, adanya jaminan kerja, status dan tanggung jawab, peraturan yang fleksibel

Dalam hal ini peneliti melihat masih ada beberapa fenomena seperti perusahaan sudah memberikan motivasi namun masih banyak karyawan yang kurang memeiliki ketekukan dalam bekerja dan masih ada beberapa karyawan dalam melakukan pekerjaan belum tepat waktu yang sesuai dengan keinginan perusahaan. Selain motivasi yang diberikan karyawan 
juga wajib mengembangkan diri dengan melakukan atau mengikuti pelatihan yang diberikan perusahaan. Menurut Widodo, (2015) pelatihan merupakan serangkaian aktivitas individu dalam meningkatkan keahlian dan pengetahuan secara sistematis sehingga mampu memiliki kinerja yang professional di bidangnya. Pelatihan adalah proses pembelajaran yang memungkinkan pegawai melaksanakan pekerjaan yang sekarang sesuai dengan standar. Dalam hal ini adanya beberapa karyawan yang kurang semangat dalam melakukan program pelatihan yang diberikan perusahaan agar karyawannya memiliki peningkatan kinerja dalam menjalankan tugas pekerjaannya karena banyak faktor yang mendukung kurang semangat karyawan seperti waktu pelatihan terlalu lama yang mungkin membuat karyawan bosan dan metode pelatihan yang digunakan masih terbilang biasa saja hal ini yang menyebabkan karyawan bermalas-malasan dalam mengikuti program pelatihan yang diberikan perusahaan.

Selain pelatihan karyawan juga harus memiliki kompetensi yang sesuai dengan jenjang pendidikan dan bidangnya dalam bekerja agar perusahaan mengetahui bahwa karyawan yang berkompetensi akan menjadi karyawan yang berkompetendalam bekerja. Kompetensi mempunyai hubungan yang erat dengan pendidikan, diharapkan akan semakin meningkatnya kompetensi seorang karyawan, karena mempunyai jenjang pendidikan yang tinggi, pengalaman serta dedikasi yang baik sehingga bisa meningkatkan kinerja karyawan.

Pengertian kompetensi menurut Moeheriono, (2014) merupakan suplemen atau pelengkap terhadap deskripsi jabatan (job description) atau spesifikasi jabatan (job specification), yang sudah kita kenal dalam manajemen sumber daya manusia selama ini. Kompetensi ini telah merinci lebih jauh lagi mengenai pengetahuan, keterampilan serta atribut personal individu seseorang. Oleh sebab itu dalam hal kompetensi masih terdapat beberapa karyawan yang masih belum mampu melaksanakan tugasnya sesuai dengan pekerjaan yang diberikan padanya.

\section{LANDASAN TEORI \\ Kepuasan Kerja}

Dalam kehidupan setiap individu selalu mengadakan bermacam-macam aktifitas. Salah satu aktivitas itu diwujudkan dengan gerakan-gerakan yang dinamakan kerja. Sedangkan salah satu faktor pendorong yang menyebabkan manusia bekerja adalah karena memiliki kebutuhan yang harus dipenuhi, yang pemunculannya sangat tergantung dari kepentingan individu (Syahputra \& Jufrizen, 2019). Menurut Wibowo, (2013), kepuasan kerja adalah merupakan tingkat perasaan senang seseorang sebagai penilaian positif terhadap pekerjaannya dan lingkungan tepat pekerjaannya. Menurut Usman, (2011) kepuasan kerja adalah terpenuhinya seluruh kebutuhan pekerja dalam melaksanakan tugasnya waktu tertentu" Menurut (Mangkunegara, 2017) menyatakan ada 2 faktor yang mempengaruhi kepuasan kerja, yaitu :1) Faktor yang ada pada diri karyawan, yaitu kecerdasan (IQ) kecakapan khusus umur, jenis kelamin, kondisi fisik, pendidikan, pengalaman kerja, kepribadian emosi cara berpikir, persepsi dan sikap kerja. 2) Faktor pekerjaan, yaitu jenis pekerjaan, struktur organisasi, pangkat (golongan) kedudukan, mutu pengawasan, jaminan finansial dan kesempatan promosi. Rivai \& Sagala, (2011) mengatakan indikator kepuasan kerja adalah 1) isi perkejaan, penampilan tugas pekerjaan yang actual dan sebagai control terhadap pekerjaan. 2) supervisi, 3) organisasi dan manajemen, 4) kesempatan untuk maju, 5) gaji, 6) rekan kerja, 7) kondisi pekerjaan.

\section{Motivasi Kerja}

Motivasi merupakan kegiatan yang mengakibatkan, menyalurkan, dan memelihara perilaku manusia (Jufrizen, 2018). Menurut Bangun, (2018), motivasi adalah suatu tindakan untuk mempengaruhi orang lain agar berperilaku (to behave) secara teratur. Manullang, (2012) 
motivasi adalah suatu kekuatan dari dalam atau luar diri manusia untuk mendorong semangat untuk mengejar sesuatu keinginan dan tujuan tertentu. Menurut Sutrisno, (2012) menyatakan faktor-faktor motivasi dibedakan atas faktor intern dan faktor ekstern yang berasal dari karyawan. Adapun penjelasan dari kedua faktor yang mempengaruhi motivasi adalah :1) faktor intern yaitu a) keinginan untuk dapat hidup,b) keinginan untuk dapat memiliki,c) keinginan untuk dapat memperoleh penghargaan, d) keinginan untuk memperoleh pengakuan,e)keinginan untuk brkuasa. 2) faktor ekstern yaitu a) kondisi lingkungan kerja, b) kompensasi yang memadai, c) supervisi yang baik, d) adanya jaminan kerja, e) status dan tanggung jawab, f) peraturan yang fleksibel. Indikator menurut (Mangkunegara, 2017) adalah sebagai berikut: 1) kerja keras, 2) orientasi masa depan, 3) tingkat cita-cita yang tinggi, 4) orientasi tugas dan keseriusan tugas, 5) usaha untuk maju, 6) ketekunan bekerja, 7) hubungan dengan rekan kerja,8) pemanfaatan waktu.

\section{Pelatihan}

Kasmir, (2016) menyatakan bahwa pelatihan merupakan proses untuk membentuk dan membekali karyawan dengan menambah keahlian, kemampuan, pengetahuan dan perilakunya artinya pelatihan akan membentuk perilaku karyawan sesuai dengan yang diharapkan perusahaan. Widodo, (2015) menyatakan :pelatihan merupakan serangkaian aktivitas individu dalam meningkatkan keahlian dan pengetahuan secara sistematis sehingga mampu memiliki kinerja yang professional di bidangnya. Pelatihan adalah proses pembelajaran yang memungkinkan pegawai melaksanakan pekerjaan yang sekarang sesuai dengan standar. Faktor-faktor mengenai pelatihan menurut Kasmir, (2016) yaitu: 1) peserta pelatihan, 2) instruktur/ pelatih, 3) materi pelatihan, 4) lokasi pelatihan, 5) lingkungan pelatihan, 6) waktu pelatihan. Mangkunegara, (2017) menyatakan faktor yang mempengaruhi kepuasan kerja adalah: 1) perbedaan individu pegawai, 2) hubungan dengan jabatan analisis, 3) motivasi, 4) partisipasi aktif, 5) seleksi peserta penataran, 6) metode pelatihan dan pengembangan. Menurut Mangkunegara (2008: 46) indikator pelatihan adalah 1) instruktur, 2) peserta, 3) materi, 4) tujuan, 5) metode, 6) sasaran. Menurut (Siagian, 2014) yaitu 1) partisipasi, 2) materi pelatihan, 3) tingkat kesulitan kerja,4) transfer pengalihan.

\section{Kompetensi}

Moeheriono, (2014) menyatakan Kompetensi merupakan suplemen atau pelengkap terhadap deskripsi jabatan (job description) atau spesifikasi jabatan (job specification), yang sudah kita kenal dalam manajemen sumber daya manusia selama ini.Kompetensi ini telah merinci lebih jauh lagi mengenai pengetahuan, keterampilan serta atribut personal individu seseorang. Kompetensi adalah suatu kemampuan yang dilandasi oleh keterampilan dan pengetahuan yang didukung oleh sikap kerja serta penerapannya dalam melaksanakan tugas dan pekerjaan di tempat kerja yang mengacu pada persyaratan kerja yang ditetapkan (Sutrisno, 2012). Kompetensi adalah karakteristik dasar yang dimiliki oleh seseorang yang dapat menciptakan kinerja yang baik dalam melakukan pekerjaan yang menhadi tanggung jawabnya (Rosmaini \& Tanjung, 2019).

Menurut Wibowo, (2013) faktor-faktor yang mempengaruhi kompetensi adalah keyakinan dan nilai-nilai, keterampilan, pengalaman, karakteristik, kepribadian, motivasi, isu emosional, budaya organisasi, dan kemampuan intelektual. Menurut (Sedarmayanti, 2014) kompetensi mencakup berbagai faktor teknis dan non teknis, kepribadian dan tingkah laku, soft skills dan hard skills, kemudian dipergunakan sebagai aspek yang dinilai banyak perusahaan untuk merekrut karyawan kedalam organisasi. Indikator kompetensi menurut (Sutrisno, 2012) yaitu 1) motives (motivasi), adalah sesuatu di mana seseorang secara konsisten berpikir 
sehingga ia melakukan tindakan. 2) traits (sifat), adalah watak yang membuat orang untuk berperilaku atau bagaimana sesorang merespon sesuatu dengan cara tertentu. 3) self concept (konsep diri), adalah sikap dan nilai-nilai yang dimiliki sesorang. 4) knowledge (pengetahuan), adalah informasi yang dimiliki seseorang untuk bidang tertentu. 5) skills (keterampilan), adalah kemampuan untuk melaksanakan suatu tertentu baik fisik maupun mental. Menurut Hutapea \& Thoha, (2008) indikator kompetensi yaitu 1) pengetahuan : kesadaran dalam bidang kognitif, misalnya seorang karyawan mengathui cara melakukan identifikasi belajar dan bagaimana melakukan pembelajaran yang baik sesuai dengan kebutuhan yang ada diperusahaan. 2) keterampilan : kemampuan mengerjakan tugas fisik atau mental tertentu. kompetensi mental atau keterampilan kognitif termasuk berpikir analitis dan konseptual. 3) sikap kerja : evaluasi positif atau negatif yang dimiliki seseorang tentang aspek-aspek lingkungan kerja. 4) tutur bahasa. 5) perilaku.

\section{METODE PENELITIAN}

Penelitian ini merupakan penelitian deskriptif kuantitatif dengan menggunakan pendekatan asosiatif dimana variabel diukur dengan skala likert. Pengumpulan data menggunakan angket (pernyataan). Objek penelitian ini adalah karyawan tetap di PT. Perkebunan Nusantara IV (Persero) Medan populasi 101 dan sampel yang digunakan sebanyak 101 karyawan yaitu menggunakan sampel jenuh. Analisis data dalam penelitian ini menggunakan teknik analisis jalur (path analysis) dibantu dengan pengolahan data menggunakan SPSS versi 24.

\section{HASIL DAN PEMBAHASAN \\ Hasil Uji Asumsi Klasik Uji Normalitas}

Uji normalitas bertujuan untuk menguji apakah dalam metode regresi, variabel terikat dan variabel bebas keduanya mempunyai distribusi normal atau tidak.Model regresi yang baik adalah data yang berdistribusi normal atau mendekati normal. (Juliandi, Irfan, \& Manurung, 2015). Kriteria pengujian adalah :

1) Jika data menyebar di sekitar garis diagonal dan mengikuti arah garis diagonal maka model regresi memenuhi asumsi normalitas.

2) Jika data menyebar jauh dari garis diagonal dan tidak megikuti garis diagonal maka model regresi tidak memenuhi asumsi normalitas

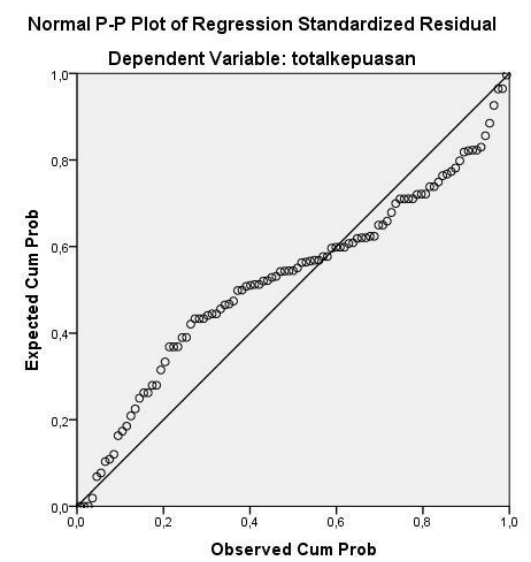

\section{Gambar 1. Hasil Uji Normalitas}


Dilihat dari gambar diatas terlihat titik-titik menunjukkan cenderung mendekati garis diagonal. Sehingga dari hasil pengujian normalitas tersebut dapat disimpulkan bahwa data yang telah diolah dan diuji merupakan data yang berdistribusi normal dan uji normalitas ini telah terpenuhi, sehingga dapat dilakukan pengujian selanjutnya yaitu analisis data dan menjawab hipotesis yang relevan menggunakan teknik statistik.

\section{Uji Multikolinieritas}

Multikolinieritas digunakan untuk menguji apakah pada model regresi ditemukan adnya korelasi yang kuat antar variabel independen.Cara yang digunakan untuk menilainya adalah dengan melihat nilai faktor inflasi varians (Variance Inflasi Factor/VIF), yang tidak melebihi 4 atau 5.

Tabel 1. Hasil Uji Multikolinieritas

Coefficients $^{\mathrm{a}}$

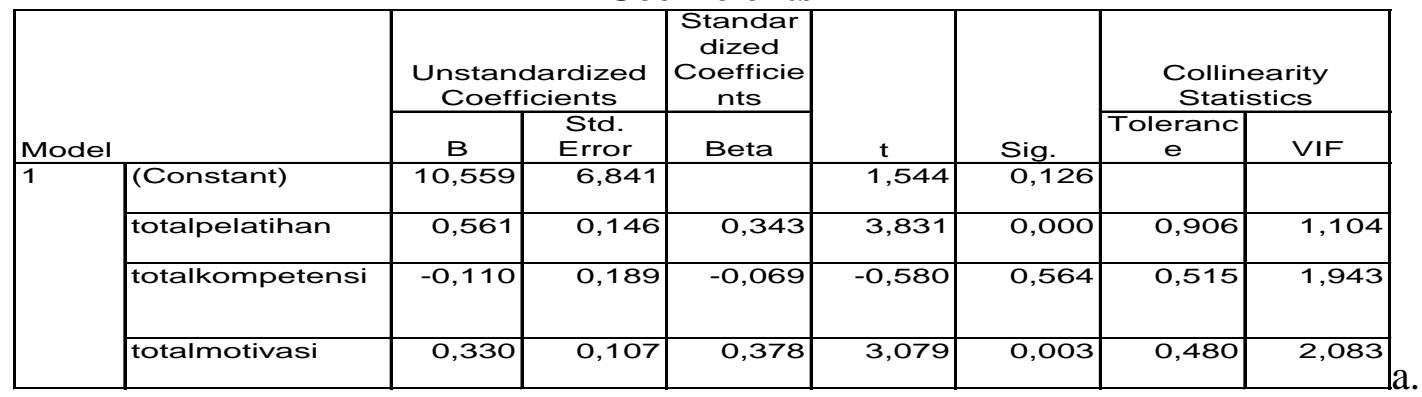

Terlihat dari tabel diatas menunjukkan bahwa nilai VIF masing-masing variabel yaitu variabel pelatihan sebesar 1.104, kompetensi sebesar 1.943 dan Motivasi Kerja sebesar 2,083. kemudian dapat diketahui bahwa nilai VIF dalam batas toleransi yang ditentukan nilai VIF tidak boleh lebih dari 4 atau 5. Jika nilai VIF melebihi 4 atau 5 maka terjadi masalah multikolineritas.

\section{Uji Heteroskedastisitas}

Pengujian ini memiliki tujuan untuk mengetahui apakah dalm model regresi terjadi ketidaksamaan varian dari residual suatu pengamatan ke pengamatan lainnya. Jika varian dari residual satu pengamatan ke pengamatan lain tetap, maka disebut homokedassitas dapat diketahui dengan melalui grafik scatterplot antar nilai prediksi varabel independen dengan nilai residualnya.

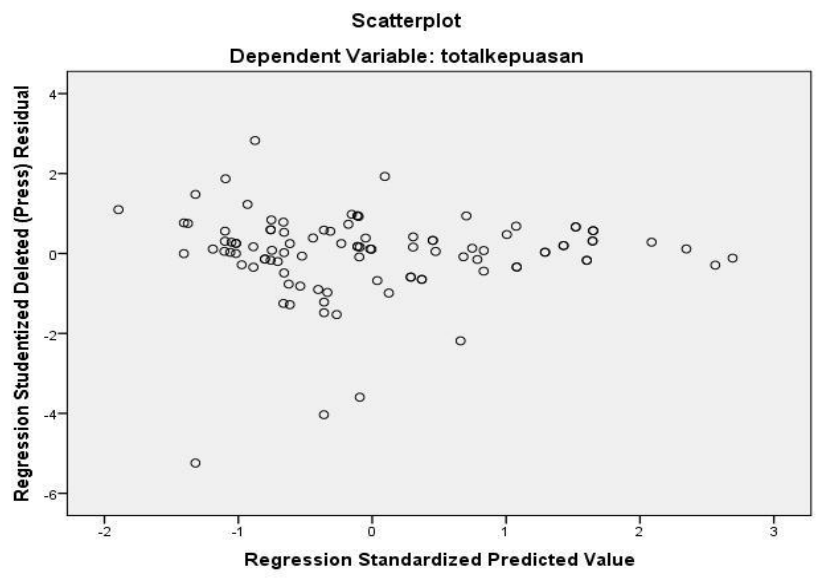

Gambar 2. Hasil Uji Heteroskedastisitas 
Dari gambar grafik diatas menunjukkan tidak ada pola yang jelas serta titik-titik menyebar diatas dan dibawah angka 0 (nol) pada sumbu Y. Maka dapat disimpulkan bahwa tidak terjadi heteroskedastisitas dalam regresi ini.

\section{Analisis Jalur}

Penelitian ini menggunakan analisis jalur (path analysis). Persamaan model analisis jalur dalam penelitian ini adalah sebagai berikut: (1) Motivasi Kerja $=0,216$ Pelatihan $+0,670$ Kompetensi $+\varepsilon_{1 ;}$ (2) Kepuasan Kerja $=0,378$ Motivasi Kerja + 0, 343 Pelatihan - 0,069 Kompetensi $+\varepsilon_{2}$.

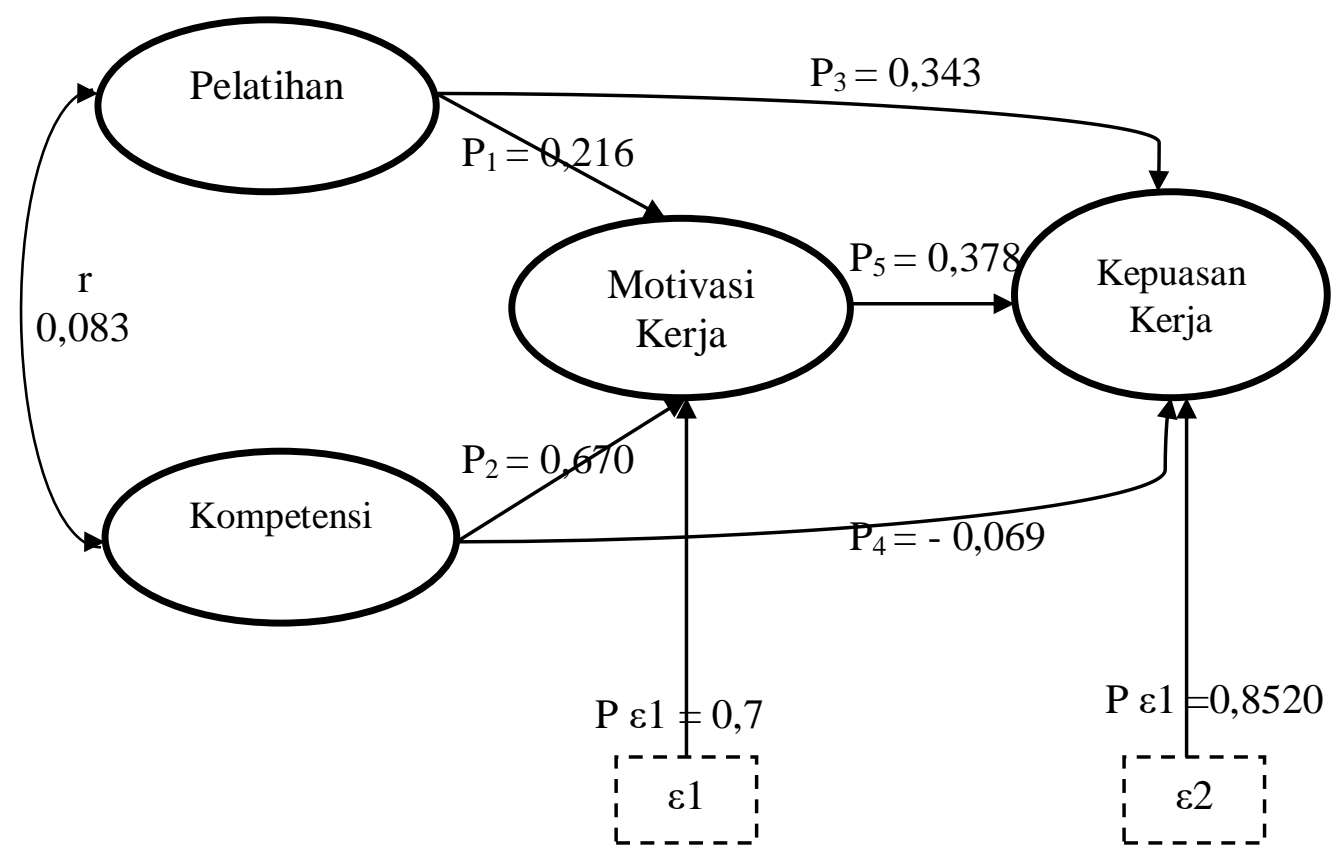

Gambar 3. Analisis Jalur

Nilai-nilai koefisien yang terlihat di dalam Gambar 1 memperlihatkan bagaimana pengaruh langsung dan tidak langsung antar-variabel di dalam penelitian ini. Interpretasi dari nilai-nilai tersebut dijelaskan dalam bagian berikut ini.

Pertama. Pengaruh langsung pelatihan terhadap motivasi kerja mempunyai nilai koefisien jalur $\left(\mathrm{p}_{1}\right)$ sebesar 0,216 positif dan nilai probabilitas (sig) sebesar 0,003 (signifikan). Nilai yang positif tersebut menunjukkan bahwa jika nilai pelatihan meningkat maka nilai motivasi kerja juga meningkat.

Kedua. Pengaruh langsung kompetensi terhadap motivasi kerja nilai koefisien jalurnya $\left(\mathrm{p}_{2}\right)$ sebesar 0,670 (positif) dan nilai probabilitas (sig) sebesar 0,000 (signifikan). Nilai yang positif tersebut menunjukkan bahwa jika nilai kompetensi meningkat maka nilai motivasi kerja juga meningkat.

Ketiga. Pengaruh langsung pelatihan terhadap kepuasan kerja mempunyai nilai koefisien jalur $\left(\mathrm{p}_{3}\right)$ sebesar 0,343 positif dan nilai probabilitas (sig) sebesar 0,000 (signifikan). Nilai yang positif tersebut menunjukkan bahwa jika nilai pelatihan meningkat maka nilai kepuasan kerja juga meningkat

Keempat. Pengaruh langsung kompetensi terhadap kepuasan kerja nilai koefisien jalurnya $\left(\mathrm{p}_{4}\right)$ sebesar $-0,069$ (negatif) dan nilai probabilitas (sig) sebesar 0,564 (tidak 
signifikan). Nilai yang negative tersebut menunjukkan bahwa jika nilai kompetensi meningkat maka nilai kepuasan akan menurun, namun dalam penelitian ini tidak signfikan.

Kelima. Pengaruh langsung motivasi kerja terhadap kepuasan kerja mempunyai nilai koefisien jalur $\left(\mathrm{p}_{5}\right)$ sebesar 0,378 positif dan nilai probabilitas (sig) sebesar 0,003 (signifikan). Nilai yang positif tersebut menunjukkan bahwa jika nilai motivasi kerja meningkat maka nilai kepuasan kerja akan meningkat.

Keenam. Pengaruh tidak langsung (indirect effect) pelatihan terhadap kepuasan kerja melalui motivasi kerja adalah sebesar $\mathrm{p}_{1}(0,216) \times \mathrm{p}_{5}(0,378)=0,086$. Sementara pengaruh langsung (direct effect) pelatihan terhadap kepuasan kerja adalah sebesar $\mathrm{p}_{3}=0,343$. Dengan demikian nilai koefisien pengaruh tidak langsung $(0,0816)<$ nilai koefisien pengaruh langsung $(0,343)$. Perbandingan tersebut menunjukkan bahwa motivasi kerja tidak berperan sebagai mediator.

Ketujuh. Pengaruh tidak langsung (indirect effect) kompetensi terhadap kepuasan kerja melalui motivasi kerja adalah sebesar $\mathrm{p}_{2}(0,670) \times \mathrm{p}_{5}(0,378)=0,25326$. Sementara pengaruh langsung (direct effect) kompetensi terhadap kepuasan kerja adalah sebesar $\mathrm{p}_{4}=-0,069$. Dengan demikian nilai koefisien pengaruh tidak langsung $(0,25326)>$ nilai koefisien pengaruh langsung $(-0,069)$. Perbandingan tersebut menunjukkan bahwa motivasi kerja berperan sebagai mediator.

\section{Pembahasan}

\section{Pengaruh Pelatihan Terhadap Motivasi Kerja}

Dari hasil penelitian menunjukkan bahwa pelatihan berpengaruh signifikan terhadap motivasi kerja yang artinya bahwa pelatihan terhadap motivasi kerja berpengaruh signifikan kerja karyawan di PT Perkebunan Nusantara IV Medan. Maknanya pelatihan yang dilakukan perusahaan untuk meningkatkan motivasi kerja karyawan sangat baik. Motivasi kerja adalah salah satu pendorong seorang karyawan untuk meningkatkan rasa kepuasan kerja karyawan disebabkan jika motivasi karyawan dalam dirinya rendah akan menyebabkan tingkat kepuasan karyawan tersebut akan berkurang dan mengakibatkan kinerja yang seharusnya meningkat jadi berkurang dan akhirnya kayawan tersebut tidak melakukan pekerjaan dengan baik sesuai keinginan perusahaan. Pelatihan yang diberikan perusahaan sudah mampu meingkatkan motivasi karyawan dalam bekerja karena karyawan mampu menguasai materi yang diberikan, instruktur pelatihan mampu berinteraksi pada karyawan hal itu membuat karyawan menjadi nyaman saat melakukan pelatihan. Manfaat pelatihan dapat dirasakan karyawan untuk meningkatkan kinerja, pelatihan dasarnya memiliki tujuan diadakannya karena ini pelatihan yang dilakukan oleh PT. Perkebunan Nusantara IV (Persero) Medan sudah melaksanakan pelatihan sesuai dengan tujuan awal. Begitupun pelatihan ini mampu meningkatkan motivasi karyawan untuk bekerja sebaik mungkin. Dan hal ini didukung oleh penelitian terdahulu yang dilakukan (Raharjo, Hamid, \& Prasetya, 2014) dan (Darmawan, Supartha, \& Rahyuda, 2017) yang menunjukkan bahwa pelatihan berpengaruh signifikan terhadap motivasi kerja. Hasil penelitian Zahra, Iram, \& Naeem, (2014) juga menyimpulkan bahwa pelatihan berpengaruh terhadap motivasi.

\section{Pengaruh Kompetensi Terhadap Motivasi Keja}

Dari hasil penelitian menunjukkan bahwa kompetensi berpengaruh signifikan terhadap motivasi kerja. Kompetensi adalah salah satu faktor yang harus dimilki setiap karyawan untuk melakuka pekerjaan yang dberikan. Jika karyawan tidak memilki kemampuan yang dimiliki karyawa tidak dapat meningkatkan motivasi dalam bekerja maka pekerjaan yang dialkukan tidak akan memenuhi syarat yang diharapkan perusahaan. Motivasi harus diiringi dengan 
kompetensi yang sesuai di dalam diri karyawan agar kinerja yang diharapkan akan terpenuhi. Kompetensi dalam perusahaan ini diawali dengan keinginan karyawan bekerja lebih baik dari rekan kerjanya, selalu berusaha memecahkan masalah yang ada di perusahaan, dan memberikan masukan kepada pimpinan dengan pengetahuan yang dimiliki, serta karyawan mampu mengerjakan pekerjaan dengan waktu yang telah ditetapkan. Hal ini bisa menjadikan karyawan termotivasi dalam bekerja karena jika seorang karyawan tidak memberikan contoh yang baik dalam pekerjaan, tidak memberikan ide dalam perusahaan tidak akan mampu meningkatkan motivasi dalam diri bekerja lebih baik etiap harinya. Penelitian ini didukung peneliti yang dilakukan juga oleh (Ngatemin \& Arumwanti, 2013) yang dilakukan menyimpulkan bahwa kompetensi berpengaruh signifikan terhadap motivasi kerja. Begitu juga hasil penelitian (Triyanto \& Sudarwati, 2014) dan (Amrulah \& Hermani, 2018) yang menunjukkan bahwa kompetensi berpengaruh terhadap motivasi kerja.

\section{Pengaruh Pelatihan Terhadap Kepuasan Kerja}

Dari hasil penelitian menunjukkan bahwa Pelatihan berpengaruh signifikan terhadap kepuasan kerja. Oleh karena itu maka dapat disimpulkan bahwa pelatihan tidak berpengaruh terhadap kepuasan kerja di PT. PN IV Medan.pelatihan mampu meningkatkan kepuasan dengan kinerja yang meningkat setelah pelatihan mampu menambah rasa percaya diri dalam bekerja. Hal demikian mendukung teori menurut Kasmir yang menyatakan bahwa pelatihan dilakukan untuk meningkatkan rasa peraya diri, menambah pengetahuan, meningkatkan motivasi, memahami lingkungan kerja, dan sebagainya. Begitu pula dengan beberapa jurnal yang ada tidak sesuai dengan refrensi yang peneliti baca Peneliti ini (Saprudin, 2018) mengatakan pelatihan berpengaruh signifikan terhadap kepuasan kerja. Hasil penelitian terdahulu lainnya diantaranya penelitian oleh (Asri, 2017); (Adisaksana, Astuti, \& Musadieq, 2015); (Pareraway, Kojo, \& Roring, 2018) menyatakan pelatihan berepengaruh signifikan terhadap kepuasan kerja.

\section{Pengaruh Kompetensi Terhadap Kepuasan Kerja}

Dari hasil penelitian menunjukkan bahwa kompetensi tidak berpengaruh terhadap Kepuasan kerja. karena kompetensi adalah kemampuan yang dimiliki oleh setiap manusia dalam dirinya juga mempengaruhi kepuasan kerja. Jika setiap karyawan memiliki kemampuan yang seharusnya dimiliki oleh karyawan yang bekerja di dalam sebuah perusahan maka keinginan perusahaan akan terpenuhi namun banyak yang tidak memiliki kemampuan yang sesuai dengan jabatan yang diberikan maka penelitian ini membuktikan jika kompetensi harus beririgan dengan kepuasan kerja agar meningkatkan kinerja karyawan di PT PN IV Medan. Hal ini tidak didukung oleh penelitian yang dilakukan (Manik \& Wiarah, 2014); (Gijoh, 2013), (Supianto, 2015) yang menyimpulkan bahwa kompetensi berpengaruh signifikan terhadap kepuasan kerja.

\section{Pengaruh Motivasi Terhadap Kepuasan Kerja}

Dari hasil penelitian menunjukkan bahwa motivasi kerja berpengaruh signifikan terhadap kepuasan kerja. Demikian pula yang teori ungkapkan bahwa motivasi kerja sangat mempengaruhi kepuaan kerja karyawan jika dalam diri adanya motivasi tinggi makan tingkat kepuasan kerja demikian pula dan dampaknya terhadapa prestasi yang dimiliki karena kepuasan seseorang dalam bekerja akan membuatnya selalu giat melakukan pekerjaan yang efektif dan denga waktu yang sesuai harapan. Penelitian ini didukung oleh penelitian sebelumnya yang meyatakan bahwa (Riyadi, Utomo, \& Masatip, 2017);(Kartika \& Kaihatu, 
2010) dan (Lukita, 2019) yang menemukan bahwa motivasi terhadap kepuasan berpengaruh secara signifikan.

\section{Pengaruh PelatihanTerhadap Kepuasan Kerja Melalui Motivasi Kerja}

Hasil penelitian ini mendapatkan Nilai koefisien pengaruh tidak langsung > pengaruh langsung (p1 x p5<p3) yakni 0,0816<0,343, maka pelatihan (X1) berpengaruh langsung terhadap Kepuasan Kerja tidak harus melalui motivasi kerja. Variabel intervening tidak begitu penting dalam penlitian ini.. Di sini terlihat bahwa Motivasi Kerja tidak merupakan variabel intervening hubungan Pelatihan dengan Kepuasan Kerja. Artinya Motivasi kerja tidak begitu penting perannya dalam model penelitian ini, yakni Motivasi Kerja tidak menjadi perantara hubungan Pelatihan dengan Kepuasan Kerja. Hal ini menyebabkan pelatihan langsung meningkatkan kepuasan tanpa pelatihan lalu termotivasi kemudian meningkatkan kepuasan.

\section{Pengaruh Kompetensi Terhadap Kepuasan Kerja Melalui Motivasi Kerja}

Penelitian ini mendapatkan nilai yakni : 0,0546 >-0,069 maka Kompetensi (X2) berpengaruh tidak langsung langsung terhadap Kepuasan Kerja (Y2) harus melalui Motivasi Kerja (Y1). Disini terlihat bahwa Motivasi Kerja (Y1) merupakan variabel intervening/memediasi/mengantarai hubungan Kompetensi (X2) dengan Kepuasan Kerja (Y2). Artinya Motivasi Kerja (Y1) begitu penting perannya dalam model penelitian ini, yakni Motivasi Kerja (Y1) menjadi perantara hubungan Kompetensi (X1) dengan Kepuasan Kerja (Y2). Dengan demikian kompetensi yang baik dalam diri karyawan akan meningkatkan motivasi dalam bekerja di perusahaan lalu akan meningkatkan rasa senang dalam diri dengan gaji yang sesuai dengan kemampuan yang dimiliki. hal ini mendukung jurnal yang dijadikan refrens oleh penliti Irfan Ullah Khan (2015) bahwa kompetensi berpengaruh terhadap kepuasan kerja.

\section{KESIMPULAN}

Berdasarkan penelitian dan pembahasan yang telah penulis lakukan, maka dalam penelitian yang berjudul pengaruh pelatihan dan kompetensi terhadap kepuasan kerja melalui motivasi kerja pada karyawan di PT. Perkebunan Nusantara IV (Persero) Medan. Maka dapat disimpulkan bahwa pelatihan berpengaruh signifikan terhadap motivasi kerja, kompetensi berpengaruh signifikan terhadap motivasi kerja, pelatihan berpengaruh signifikan terhadap kepuasan kerja. Kompetensi tidak berpengaruh signifikan terhadap kepuasan kerja. Motivasi kerja berpengaruh signifikan terhadap kepuasan kerja. Pelatihan berpengaruh langsung terhadap Kepuasan Kerja tidak harus melalui Motivasi Kerja. Dan kompetensi berpengaruh tidak langsung langsung terhadap Kepuasan Kerja harus melalui Motivasi Kerja.

\section{DAFTAR PUSTAKA}

Adisaksana, H., Astuti, E. S., \& Musadieq, M. Al. (2015). Pengaruh Pelatihan Kerja dan Insentif Terhadap Kepuasan Kerja dan Dampaknya Terhadap Komitmen Organisasional. WACANA : Jurnal Sosial Dan Humaniora, 18(2), 136-145. https://doi.org/10.21776/ub.wacana.2015.018.02.7

Amrulah, M. Y., \& Hermani, A. (2018). Pengaruh Kompetensi Dan Kompensasi Terhadap Motivasi Kerja Karyawan di Divisi Body \& Rangka CV. Laksana. Jurnal Ilmu Administrasi Bisnis, 7(4), 236-247.

Arianty, N., Bahagia, R., Lubis, A. A., \& Siswadi, Y. (2016). Manajemen Sumber Daya Manusia. Medan: Perdana Publishing.

Asri, A. (2017). Pengaruh Dimensi Pelatihan Terhadap Kepuasan Kerja Guru SMK Nurul 
Falah Pekanbaru. Jurnal Wira Ekonomi Mikroskil, 7(2), 219-226.

Bangun, W. (2018). Manajemen Sumber Daya Manusia. Jakarta: Erlangga.

Darmawan, Y. Y., Supartha, W. G., \& Rahyuda, A. G. (2017). Pengaruh Pelatihan Terhadap Motivasi Kerja dan Kinerja di Prama Sanur Beach-Bali. E-Jurnal Ekonomi Dan Bisnis Universitas Udayana, 6(3), 1265-1290.

Gijoh, R. (2013). Motivasi, Kompetensi Dan Budaya Kerja Pengaruhnya Terhadap Kepuasan Kerja Karyawan Outsourcing Pada Hotel Sintesa Peninsula Manado. Jurnal EMBA: Jurnal Riset Ekonomi, Manajemen, Bisnis Dan Akuntansi, 1(4), 1963-1973. https://doi.org/10.35794/emba.v1i4.3404

Hutapea, P., \& Thoha, N. (2008). Kompetensi Plus. Jakarta: PT Gramedia Pustaka Utama.

Jufrizen, J. (2016). Efek Mediasi Kepuasan Kerja Pada Pengaruh Kompensasi Terhadap Kinerja Karyawan. Jurnal Ilmiah Manajemen Dan Bisnis, 17(1).

Jufrizen, J. (2017). Pengaruh kemampuan dan motivasi terhadap kinerja perawat Studi pada Rumah Sakit Umum Madani Medan. Jurnal Riset Sains Manajemen, 1(1), 27-34. https://doi.org/10.5281/zenodo.1036809

Jufrizen, J. (2018). Peran Motivasi Kerja dalam Memoderasi Pengaruh Kompensasi dan Disiplin Kerja terhadap Kinerja Karyawan. In Prosiding: The National Conferences Management and Business (NCMAB) 2018 (pp. 405-424).

Jufrizen, J., \& Pulungan, D. R. (2017). Implementation of Incentive and Career Development of Performance with Motivation as an Intervening Variable. In Proceedings of AICS-Social Sciences (pp. 441-446).

Juliandi, A., Irfan, \& Manurung, S. (2015). Metodologi Penelitian Bisnis Konsep dan Aplikasi. Medan: UMSU Press.

Kartika, E. W., \& Kaihatu, T. S. (2010). Analisis Pengaruh Motivasi Kerja Terhadap Kepuasan Kerja (Studi Kasus Pada Karyawan Restoran Di Pakuwon Food Festival Surabaya). Jurnal Manajemen Dan Kewirausahaan, 12(1), 100-112. https://doi.org/10.9744/jmk.12.1.pp.\%20100-112

Kasmir. (2016). Manajemen Sumber Daya Manusia (Teori dan Praktik). Jakarta: PT. Raja Grafindo Persada.

Lukita, C. (2019). Pengaruh Kepemimpinan Transformasional, Motivasi Kerja Dan Budaya Organisasi Terhadap Kepuasan Kerja Serta Dampaknya Pada Kinerja Pegawai. Ecodemica : Jurnal Ekonomi, Manajemen \& Bisnis Universitas Bina Sarana Informatika, 3(2), 269-281.

Mangkunegara, A. A. P. (2017). Manajemen Sumber Daya Manusia (Bandung). Remaja Rosdakarya.

Manik, E., \& Wiarah, W. (2014). Pengaruh Kompetensi Dan Kompensasi Terhadap Kepuasan Kerja Serta Implikasinya Pada Kinerja Paramesia Di RS Cibabat Kota Cimahi. Jurnal Ekonomi, Bisnis \& Entrepreneurship, 8(2), 62-72.

Manullang, M. (2012). Dasar-Dasar Manajemen. Yogyakarta: Gadjah Mada University Press. Moeheriono, M. (2014). Pengukuran Kinerja Berbasis Kompetensi (Revisi). Jakarta: PT Raja Grafindo Persada.

Mujiatun, S., Jufrizen, J., \& Ritonga, P. (2019). Model Kelelahan Emosional: Antaseden Dan Dampaknya Terhadap Kepuasan Kerja Dan Komitmen Organisasi Dosen. MIX: Jurnal Ilmiah Manajemen, 9(3), 447-465.

Ngatemin, N., \& Arumwanti, W. (2013). Pengaruh Kompetensi Dan Kompensasi Terhadap Motivasi Kerja Karyawan Hotel di Kabupaten Karo Provinsi Sumatera Utara. Jurnal Riset Akuntansi Dan Bisnis, 13(1), 80-92. https://doi.org/10.30596/jrab.v13i1.165

Pareraway, A. S., Kojo, C., \& Roring, F. (2018). Pengaruh Lingkungan Kerja, Pelatihan Dan 
Pemberdayaan SDM Terhadap Kepuasan Kerja Karyawan PT. PLN (Persero) Wilayah Suluttenggo. Jurnal EMBA: Jurnal Riset Ekonomi, Manajemen, Bisnis Dan Akuntansi, 6(3). https://doi.org/10.35794/emba.v6i3.20665

Raharjo, R. P., Hamid, D., \& Prasetya, A. (2014). Pengaruh Pelatihan Terhadap Motivasi Kerja Dan Kinerja Pegawai (Studi Pada Pegawai Balai Besar Pelatihan Pertanian (BBPP) KetindanLawang). Jurnal Administrasi Bisnis (JAB), 15(2), 1-10.

Rivai, V., \& Sagala, E. J. (2011). Manajemen Sumber Daya Manusia untuk Perusahaan dari Teori ke Praktik. Jakarta: PT Raja Grafindo Persada.

Riyadi, H., Utomo, B. S., \& Masatip, A. (2017). Pengaruh Komunikasi Dan Kompetensi Terhadap Kepuasan Kerja Serta Implikasinya Pada Kinerja Dosen Perguruan Tinggi Pariwisata Swasta Di Jawa Barat. Tourism and Hospitality Essentials (THE) Journal, 7(2), 73-90.

Rosmaini, R., \& Tanjung, H. (2019). Pengaruh Kompetensi, Motivasi Dan Kepuasan Kerja Terhadap Kinerja Pegawai. Maneggio: Jurnal Ilmiah Magister Manajemen, 2(1), 1-15. https://doi.org/10.30596/maneggio.v2i1.3366

Saprudin, S. (2018). Pengaruh Pelatihan dan Kompetensi Terhadap Kepuasan Kerja Karyawan. Journal of Information System, Applied, Management, Accounting and Research, 2(1), $14-19$.

Sedarmayanti. (2014). Sumber Daya Manusia dan Produktivitas Kerja. Jakarta: Mandar Maju. Siagian, S. P. (2014). Manajemen Sumber Daya Manusia. Jakarta: Bumi Aksara.

Supianto, Y. (2015). Pengaruh Kompensasi, Kompetensi Dan Komitmen Organisasional Terhadap Kepuasan Dan Kinerja. Jurnal Economia, 11(2), 118-131.

Sutrisno, E. (2012). Manajemen Sumber Daya Manusia. Jakarta: Kencana Prenada Media Group.

Syahputra, I., \& Jufrizen, J. (2019). Pengaruh Diklat, Promosi, Dan Kepuasan Kerja Terhadap Kinerja Pegawai. Maneggio: Jurnal Ilmiah Magister Manajemen, 2(1), 104-116. https://doi.org/10.30596/maneggio.v2i1.3364

Triyanto, A., \& Sudarwati, S. (2014). Pengaruh Kompetensi Dan Penghargaan Terhadap Motivasi Kerja Karyawan PT KAI di Stasiun Sragen. Jurnal Paradigma, 12(1), 26-40.

Usman, H. (2011). Manajemen. Jakarta: Bumi Aksara.

Wibowo. (2013). Manajemen Kinerja. Jakarta: Rajawali Pers.

Widodo, S. E. (2015). Manajemen Pengembangan Sumber Daya Manusia. Yogyakarta: Pustaka Pelajar.

Zahra, S., Iram, A., \& Naeem, H. (2014). Employee Training and Its Effect on Employees' Job Motivation and Commitment: Developing and Proposing a Conceptual Model. IOSR Journal of Business and Management (IOSR-JBM), 16(9), 60-68. 